\title{
Inclusive Education in Primary School: How Teachers' Engagement Mediates the Relationship between Teachers' Self-Efficacy and Instructional Support
}

\author{
Lia Febrian $^{1}$ and Farida Kurniawati ${ }^{2}$ \\ \{lia.febrian@gmail.com ${ }^{1}$,faridal@ui.ac.id ${ }^{2}$ \} \\ Faculty of Psychology, Universitas Indonesia, Kampus UI, Depok, Indonesia ${ }^{I}$
}

\begin{abstract}
The implementation of inclusive education has challenged teachers in delivering instructional support. This study was based on Bandura's research stating that self-efficacy is a context-sensible variable depending on the task, which is the implementation of inclusive education. Within the Job Demand-Resource (JD-R) framework, this study aims to know whether teachers' self-efficacy and instructional support are mediated by teachers' engagement in the inclusive classroom. A total of 242 teachers coming from 20 primary inclusive schools were involved in this study. Using the Hayes mediation process to analyze the data, the findings revealed that teachers' selfefficacy and instructional support in an inclusive classroom are partially mediated by teachers' engagement.
\end{abstract}

Keywords: Teacher, Inclusive education, Instructional support, Self-efficacy, Teachers' engagement, Primary school.

\section{Introduction}

As the paradigm of the world educational system shifts to the way of inclusive education, Indonesia's educational system in 2003 also starting to comprehend inclusive education. National Education System Consitution No.20 is the foundation of the implementation of inclusive education throughout schools in Indonesia, from primary to general high and higher vocational schools [1]. Inclusive education is the inclusion of special needs students (SEN) inregular schools [2]. Inaninclusive school, SEN and regular students can learn and interact together in the same classroom with the aim that students with SEN participate fully in social life [3]. SEN students are those differ from others in physical characteristics and/or in mental characteristics, sensory capabilities, communication skills, emotional development and behavior [4].

In Indonesia's, the implementation of inclusive education faced some challenges, primarily from the teachers charged with carrying out inclusive education as well as those who make changes in the classroom teaching process [5]. Many teachers stated that these changes are not easy because they are not ready to manage their classroom in inclusive setting [6] or to give the required instructional support [7] [details removed for peer review]. Schumm and Vaughn, in Emmer [6], found that only 39\% of teachers were ready to run an inclusive classroom. This was disheartening because the implementation of inclusive education is not only about physical integration like providing the facilities and services, but also about giving 
those special needs children the chance to get the proper instructional support, which will not happen without teachers' willing participation [8].

Research done by Hamre and Pianta in 2005 stated the importance of instructional support is also in line with the thinking in developmental psychology that good instructional support would give students better academic results According to [6], instructional support can be defined as teachers' effort to give feedback in order to give students the opportunities to develop their higher-order thinking skills, learning and practicing a language, and communicating with their teachers regarding their learning process. Research shows that there are differences between students who acquire new knowledge and students who learn usable knowledge by connecting their new knowledge with their pre-knowledge, and these differences depend on the instructional support that the teacher gives in class [9].

Kulik and Kulik [10] also found that when teachers give feedback while interacting with a student,thestudent's conceptualandlanguageability will develop. Giving feedback also helps the student control their frustration when they are not able to understand the topic of instruction. Teachers' instructional support, in the end, will create a fun learning process that will support student knowledge [11], [12].

Research by Zee and Koomen [13] also found that other factors besides instructional support also play an important role in the success of implementation, which is the teacher's confident on their ability to teach special needs students in their classroom. This is called self-efficacy [14]. Teachers that have a low level of self-efficacy will give little effort and think that they are not able to make the changes in their teaching to accommodate special needs students. On the contrary, teachers who have a high level of self-efficacy will give a consistently greater effort to make changes, such as providing the proper instructional support [15].

Bandura [16] stated that self-efficacy is a context-sensitive variable and depends on the activities that need to be done [5]. It is thus important to specify that self-efficacy in this researchis self-efficacy in implementinganinclusive education that determines the instructional support teachers give in class [17]. Much research regarding teachers' self-efficacy in education has been done, but research about the self-efficacy of teachers' who teach in an inclusive education context is still limited [18].

The Job-Demand Resources (JD-R) theoretical framework developed by Baker \& Demerouti [19] stated that a teacher's self-efficacy in implementing inclusive education reflects an aspect of oneself that is related to endurance and one's capability of discipline and dedication. The aspect of the self in JD-R's theoretical framework is commonly known as a personal resource. This personal resource is something that belongs to a person and includes physical, psychological, social, and organizational traits, and an attitude of positive achievement and self-improvement [20]. Based on the statement about personal resource mentioned by Bakker \& Bal [20] teachers' self-efficacy in implementing inclusive education is a psychological resource that provides teachers the energy to stimulate their self-learning and self-improving to give their best instructional support in class.

JD-R is a theory developed by Demerouti et al. [21] to define employees' key performance with their personal resources to create a working engagement. Higher working engagement will improve employee performance through the motivational process. Through the motivational process [19], teachers' self-efficacy in implementing inclusive education acts as an intrinsic motivation to enhance their aspiration to improve and successfully achieve their goal of giving good and proper instructional support to students.

The motivational process in JD-R happens when personal resources directly affect the employees' performance, and this is mediated by the employees' working engagement [21]. 
The most important predictor of better work performance is self-efficacy [22], which is why this research aims to find out the impact of teachers' self-efficacy in implementing inclusive education using instructional support and engagement as the mediator in this relationship in the inclusive education context.

According to Bakker and Demerouti [19], teachers' engagement can be seen through the effort in enhancing positive energy and their determination in teaching, being highly dedicated, having enough courage to face the challenges, and giving their full concentration while teaching. As Rutter and Jacobson [23] said, teachers with high working engagement will focus more on their teaching quality, which can be observed in the classroom by their giving instructional support to all students.

Using the JD-R theoretical framework, we can put instructional support, teachers' selfefficacy, and teachers' engagement in a proper model to test whether teachers' engagement can mediate the relationship between teachers' self-efficacy and their instructional support. The JD-R theoretical framework stated that one's personal resource could motivate a person to become more engaged in their work and as a result, their work performance will increase [19]. This research places teachers' self-efficacy in practicing inclusive education as the personal resource [24] and instructional support as the work performance of the teacher [25]

Therefore, in this paper, we address the following research question: Does teachers' engagement mediate the relationship between teachers' efficacy and their instructional support? We can see the research model in Figure 1.

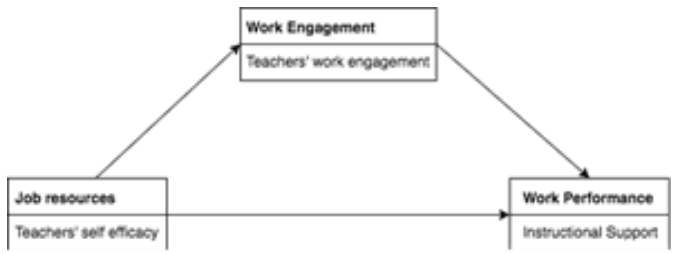

Fig. 1. JD-R Theoretical Model

\section{Methodolgy}

Participants were chosen based on a purposive sampling method. The researcher first obtained the database of primary inclusive schools from the Education Ministry of Indonesia, then visited the schools on the list to meet the principals and ask for their permission to give the questionnaire to their teachers. After permission was granted, the researcher handed the questionnaire to the teachers. Before filling out the questionnaire, the participants were asked to give consent in their by filling out the informed consent form. A total of 242 teachers from 20 primary inclusive schools in Jakarta participated in this research. 28 of them $(11.6 \%)$ were teachers from private schools, and most were women (201 or $83.1 \%$ ) while 41 or $17.6 \%$ were male. Based on the demographic data, $88.4 \%$ of the teachers teach in public schools $(n=214)$ and $11.6 \%$ teach in private schools $(n=28)$. Most had the educational level of a Bachelor's degree (95.5\%). 
Table 1. Characteristics of Teachers $(\mathrm{N}=242)$

\begin{tabular}{llll}
\hline Demographic Variable & & $\mathrm{N}$ & $\%$ \\
\hline Gender & Male & 41 & 16.9 \\
& Female & 201 & 83.1 \\
Education Level & High School & 2 & 0.8 \\
& Diploma & 1 & 0.4 \\
& Bachelor's & 231 & 95.5 \\
& Degree & 18 & 3.3 \\
School Type & Mastre's Degree & & \\
& Private & 28 & 11.6 \\
& Public & 214 & 88.4 \\
\hline
\end{tabular}

In this research, teachers' instructional support was measured using the Instructional Support instrument developed by Author [7], [details removed for peer review]. This instrument is the product of the Classroom Assessment Scoring System (CLASS) by Allen, Gregory, Mikami, Lun, Hamre, \& Pianta, 2013). The instrument had good reliability with $\alpha>$ $0.70(0.819)$ and consisted of 11 items representing the three dimensions of instructional support, which are content understanding $(\mathrm{n}=5)$, analysis and problem solving $(n=2)$, and quality of feedback $(n=4)$. This instrument used a self-reporting questionnaire using a Likert-type scale that ranged from 1 to $4(1=$ strongly disagree, $4=$ strongly agree). The owners of the instrument permitted the instrument's use for research purposes.

The teachers' self-efficacy was measured using the Teacher Efficacy in Inclusive Practice (TEIP) developed by Sharman, Loreman, and Forlin [5] while their engagement was measured using the Engaged Teacher Scale (ETS) develop by [26]. The researcher contacted the owner for permission to use their instrument for this study and received it. Once permission was given, the researcher began the adaptation process [27] by doing forward translation of every item in English to Bahasa by two interpreters and then resolving those into a single interpretation. The researcher then did the back translation by interpreting the instrument from Bahasa into English to compare it with the original items. Two lecturers whose expertise is in educational psychology from the University of Indonesia reviewed and approved the instrument, after which a pre-test was done with thirty primary inclusive school teachers in Jakarta and Bandung to ensure that teachers could understand the instrument well.

In this research, the TEIP posed good reliability scores with $\alpha>0.70(0.896)$ and consists of 18 items representing the three dimensions of teachers' self-efficacy in inclusive practices, which are efficacy to use inclusive instruction $(n=6)$, efficacy in managing behavior $(n=6)$, and efficacy in collaboration $(n=6)$. This instrument uses a self-reporting questionnaire with a Likert-type scale that ranged from 1 to $4(1=$ strongly disagree, $4=$ strongly agree).

The ETS also posed good reliability scores with $\alpha>0.70(0.958)$ and consistsof 44 itemsrepresenting the four dimensions of teachers' engagement: cognitive $(n=10)$, emotional $(n=12)$, social engagement with student $(n=12)$, and social engagement with colleagues $(n=$ 12). The questionnaire used a Likert-type scale that ranged from 1 to 4 ( 1 = strongly disagree, $4=$ strongly agree).

To answer the research questions, a Pearson correlation test and Hayes regression analysis were used to analyzing the mediation model of the teachers' engagement. 


\section{Result}

Results of data analysis of the three variables using Pearson show a significant correlation as seen in Table 2 below.

Tabel 2. Results of data analysis of the three variables

\begin{tabular}{lccccc}
\hline & $\mathrm{M}$ & $S D$ & 1 & 2 & 3 \\
\hline $\begin{array}{l}\text { Self- } \\
\text { Efficacy in }\end{array}$ & 56.24 & 6.37 & & $.606^{* *}$ & $.536^{* *}$ \\
$\begin{array}{l}\text { Inclusive } \\
\text { Practice }\end{array}$ & & & & & \\
$\begin{array}{l}\text { Teacher } \\
\text { Engagement }\end{array}$ & 152.9615 .34 & .606 & \\
& & & $* *$ & & \\
& & & & & \\
$\begin{array}{l}\text { Instructional } \\
\text { Support }\end{array}$ & 39.06 & 3.81 & .536 & $.727^{* *}$ & \\
\hline
\end{tabular}

The result of the Pearson correlation coefficient in Table 2 shows that self-efficacy in inclusive practice is positively correlated with teachers' engagement $(r=.606, p<.01)$, which means that self-efficacy in inclusive practice will influence teacher's engagement as much as $37 \%$. Table 2 also shows that self-efficacy in inclusive practice is correlated positively with instructional support $(\mathrm{r}=.536, \mathrm{p}<.01)$, which means that self-efficacy in inclusive practice will influence instructional support as much as $29 \%$. From Table 2 , we can conclude that teachers' engagement was also found to correlate positively with instructional support ( $\mathrm{r}=$ $.727, \mathrm{p}<.01$ ), which means that teachers' engagement will influence instructional support as much as $53 \%$.

To answer the research question whether teachers' engagement mediates the relationship between teachers' self-efficacy with their instruction support, Hayes mediation process was used. Placing instructional support as the dependent variable, teachers' self-efficacy as the independent variable, and teachers' engagement as the mediator, the statistical results are presented in Figure 2.

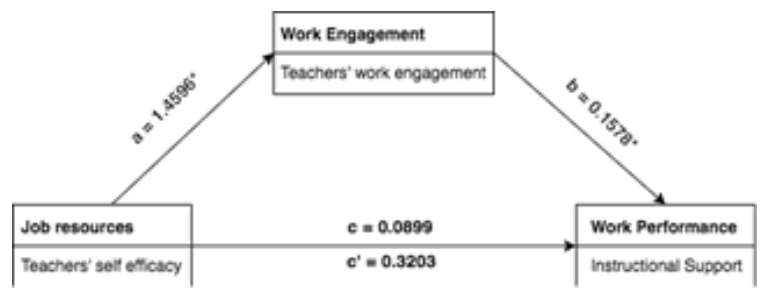

Fig. 2. The Regression Coefficient of the Relationship between teachers' Self-efficacy in Inclusive Practice and Instructional Support Mediated by Teachers' Engagement

From the statistical analysis using SPSS and the Hayes mediation as described in Figure 2 , the conclusion isthat teachers' self-efficacy significantly predicts teachers' work engagement with the coefficient $\mathrm{a}=1.4596, \mathrm{SE}=.129, \mathrm{p}<.05$ and instructional support with $\mathrm{c}=.0899, \mathrm{SE}=.0414, \mathrm{p}<.05$. The results also showed that teachers' work engagement 
significantly predicts instructional support with the coefficient $\mathrm{b}=0.1578, \mathrm{SE}=.0218$. The direct effect of teachers' self-efficacy with teacher's engagement toward instructional support $\mathrm{c}^{\prime}=-.3203, \mathrm{SE}=.0327, \mathrm{p}<.05$, showing that self-efficacy still significantly predicts instructional support when involving teachers' engagement variable. Comparing the result between $\mathrm{c}$ and c', we can conclude a significant difference in the relationship between teachers' self-efficacy and instructional support with and without their engagement With the presence of teachers' engagement, the relationship between their self-efficacy and instructional support becomes stronger, and thus the conclusion is teachers' engagement does mediate the relationship between teachers' efficacy with their instructional support.

\section{Discussion}

Thetheoretical frameworkinJD-R islesspopular in the education field [19] because this mode is popularly applied in office working context. The education field should try to use this model more because this model gives more space to analyze the connection between teachers' self-efficacy in inclusive practice, teachers' engagement and teachers' performance in their instructional support in the context of implementing inclusive practices.

The result of this research shows how teachers' involvement will mediate the connection between teachers' efficacy in implementing inclusive education and their teaching method partially. This means that teachers' engagement is not the single factor that influence the relationship between teachers' self-efficacy in implementing inclusive education with their teaching methods. Conducting research to another variable will give more comprehensive results. This research then can be used as the based in developing teachers' training program in preparing them to teach in the context of inclusive education. According to the research conducted by Marhamah [28] the other significant variable to be considered is teachers' attitude.

The result of this research goes in line with the theoretical framework about motivational job resources [19], which stated that teachers' self-efficacy in inclusive education as personal resources that fuels up positive energy and attitude in order to perform the key indicators in terms of manifesting the proper teaching method [29]. This research also shows that the teachers' belief in their own ability is in correlation with how much effort they will give in teaching such as the teachers' determination to solve difficult teaching condition as in inclusive classrooms by giving the necessary instructional support needed by the student [15].

Furthermore, in defining the theory of JD-R, Bakker and Demerouti [30], explained the inevitable aspect, i.e. job demands, that will influence the connection between self-efficacy in inclusive education as personal resources with engagement rate and teaching method as teachers' key indicator performance. As the job demands aspect exists, working pressure (emotionally, physically, and also mentally) undeniably appear as well. Within this context, these job demand aspects can be considered as the other variable, which influences the mediating relation.

According to the data analysis, there is a connection between teachers' self-efficacy and teachers' engagement. Therefore, teachers with a high rate of self-efficacy in inclusive education will become a teacher with high engagement rate. It is in line with the research done by Skaalvik and Skaalvik [31] that stated self-efficacy will give a prediction towards teachers' engagement rate. According to Bandura, in Shreve [32] there are three factors that influence teachers' self-efficacy, such as pre-service training, teacher with training will have more 
confidence in their ability in modifying their instruction and dealing with SEN students in class; school support, when the principal and fellow teachers give positive support for the teachers it will boost the teachers self-efficacy level; and last the type of disability from the SEN students. Teachers tend to feel more efficacious when dealing with students with a physical disability than a student with an emotional and behavioral disability. More

elaborating research can be done to further investigate the factors that can boost up teachers self-efficacy in inclusive practices.

Research stated that teachers' engagement would be the buffer for those stressful teachers who desire to quit their job [33]. The JD-R framework also elaborates that if the work engagement level is low, then it is most likely the teachers will feel burn out and eventually quit from their job as a teacher regardless of how complex their job is [34]. Considering the multiple challenges in implementing inclusive education related to teachers' readiness in executing it, therefore, teachers' engagement is crucial to handle and overcome the stresses experienced by those teachers. Thus, research to know the factors that increase the level of teachers' engagement in inclusive education is crucial.

\section{Conclusion}

The implementation of inclusive education faces many problems, one of which is teachers' readiness to implement change in their classroom. Much research has shown that teachers face a great deal of difficulty in adapting and modifying their instructional support to accommodate all the students in their classroom including SEN students. Implementing inclusive education is not merely providing the same space in the same classroom, but also providing the necessary support in developing the students' thinking skills by giving the appropriate instructional support in class.

This research is a preliminary study regarding teachers' engagement as the mediator of the relationship between teachers' self-efficacy in implementing inclusive education and their instructional support in Jakarta's inclusive primary schools. The researcher hopes that this research can be developed by adding a new variable such as teachers' attitude or workings' job demands to accomplish a more comprehensive correlation between teachers' self-efficacy in implementing inclusive education and their instructional support.

For further research, it is recommended to use not only a questionnaire, which may have high social desirability [29] but also other methods, such as field observation. The researcher can conduct field observation by recording the teacher while they are teaching in the classroom and comparing the questionnaire with the recording. Adding up the information about the number of training hours in implementing an inclusive education that the teachers have into the questionnaire may provide more data to help further analyze the correlation between the variables. The researchers can then analyze how providing training influences teachers' self-efficacy and affects the teachers' engagement and instructional support. By doing this, the research results can give a more concrete recommendation to the school for arranging the necessary teacher training.

Concerning the research question, it can be concluded that teachers' self-efficacy and instructional support in an inclusive classroom are partially mediated by teachers' engagement and teachers' engagement is positively mediate the relationship between teachers' selfefficacy and their instructional support. However, the level of the teachers' engagement will mediate how much instructional support the teachers will give in their classroom to accommodate all of the students, including SEN students. The more engaged the teacher, the more driven he or she will be to give more instructional support to students. 
The implication of this research finding for teachers who teach in inclusive education setting are that it is important for teachers in primary inclusive schools to have self-efficacy in teaching within an inclusive setting because teachers with high self-efficacy will give the instructional support needed by students in the classroom. It is important for teachers in inclusive setting to have and build their self-efficacy. This can be done by equipping themselves with proper training and expanding their knowledge about inclusive education. This teachers training should not only be a concern to the teachers personally but also by the school as the facilitator of the education process. If the teachers have proper training that increase their self-efficacy then they can give a better instructional support needed by all the student including the SEN students in learning.

School also need to consider ways to improving the teachers' engagement level in learning is also an important factor. By increasing the teachers' engagement level, the teachers will have higher motivation to improve their performance in teaching, having more positive energy and more dedication in teaching. The teachers will also have enough courage to face the challenges of teaching in inclusive setting.

\section{References}

[1] Sunardi, Yusuf, M., Gunarhadi, Priyono, \& Yeager, J. L.: The implementation of inclusive education for students with special needs in Indonesia. Excellence in Higher Education, 2(1), 110. (2011). doi:10.5195/ehe.2011.27.

[2] Hull, J. R.: General classroom and special education teachers' attitudes toward and perceptions of inclusion in relation to student (2005).

[3] Leatherman, J. M., \& Niemeyer, J. A.: Teachers' attitudes toward inclusion: Factors influencing classroom practice. Journal of Early Childhood Teacher Education, 26, 23-26. . (2005).

[4] Kirk, S., Gallagher. J.J, Coleman, M.R., \& Anastasiow, N.: Educating Exceptional Children. New York: Houghton Miffl in Harcourt Publishing Company. (2009).

[5] Sharma, U., Loreman, T., \& Forlin, C.: Measuring teacher efficacy to implement inclusive practices. Journal of Research in Special Educational Needs, 12. (2011). doi:10.111/j.14713802.2011.01200.x

[6] Emmer, E. T., \& Stough, L. M. (2001). Classroom Management: A Critical Part of Educational Psychology, with Implications for Teacher Education. Educational Psychologist, 36, 103-112.

[7] Kurniawati, F., De Boer, A., Minnaert, A.E.M.G., \& Mangunsong, F.: Evaluating the effect of a teacher training programme on the primary teachers' attitudes, knowledge and teaching strategies regarding special educational needs, Educational Psychology, (2016). doi: 10.1080/01443410.2016.1176125.

[8] Peters, S. J. : "Education for all" A Historical analysis of international inclusive education policy and individuals with disabilities, Journal of disability policy studies, 18 (2), 98-108. (2007)

[9] Bransford, J.D., A.L Brown and R.R. Cocking (eds.): How People Learn: Brain, Mind, Experience, and School. Washington D.C.: National Academy Press. (2000).

[10] Kulik, J. A., \& Kulik, C.-L. C. Timing of Feedback and Verbal Learning. Review of Educational Research, 58(1), 79-97. (1988). doi:10.3102/00346543058001079

[11] Allen, J., Gregory, A., Mikami, A., Lun, J., Hamre, B., \& Pianta, R.: Observations of effective teacherstudent interactions in secondary school classroom: Predicting student achievement with the classroom assessment scoring system-secondary. School Psychology Review, 42, 76-98. (2013).

[12] Curby, T., Rimm-Kaufman, S., \& Abry, T.: Do emotional support and classroom organization earlier in the year set the stage for higher quality instruction? Journal Of School Psychology, 51, 557-569. (2013). doi:10.1016/j.jsp.2013.06.001 
[13] Zee, M., \& Koomen, H.: Teacher self-efficacy and its effects on classroom processes, student academic adjustment, and teacher well-being: A synthesis of 40 years of research. Review of Educational Research, 86, 981-1015. (2016). doi:10.3102/0034654315626801

[14] Barco, Margaret Jackson. The Relationship Between Secondary General Education Teachers Self-Efficacy And Attitudes As They Relate To Teaching Learning Disabled Students In The Inclusive Setting. (2007)

[15] Lamorey, S., \& Wilcox, M. J.: Early intervention practitioners' self-efficacy: a measure and its applications. Early Childhood Research Quarterly, 20, 69-84. (2005). doi:10.1016/j.ecresq.2005.01.003

[16] Bandura, A.: Self-efficacy: Toward a unifying theory of behavioral change. Psychological Review, 84, 191-215. (1977). doi:10.1037//0033295x.84.2.191

[17] Pajares, F.: Self-Efficacy Beliefs in Academic Settings. Review of Educational Research, 66(4), 543-578. (1996). doi:10.3102/00346543066004543

[18] Tschannen-Moran, M., \& Hoy, A. W.: The differential antecedents of self- efficacy beliefs of novice and experienced teachers. Teaching and Teacher Education, 23, 944-956. (2007). doi:10.1016/j.tate.2006.05.003.

[19] Bakker, A. B., \& Demerouti, E.: The Job Demands-Resources model: State of the art. Journal of Managerial Psychology, 22, 309-328. (2007).

[20] Bakker, A., \& Bal, M. : Weekly work engagement and performance: A study among starting teachers. Journal of Occupational and Organizational Psychology, 83, 189-206. (2010). http://dx.doi.org/10.1348/096317909x402596.

[21] Demerouti, E., Bakker, A. B., Nachreiner, F., \& Schaufeli, W. B.: The job demands-resources model of burnout. Journal of Applied Psychology, 86(3), 499-512. (2001). doi:10.1037/00219010.86.3.499

[22] Bakker, A. B., Demerouti, E., \& Verbeke, W.: Using the job demands-resources model to predict burnout and performance. Human Resource Management,43, 83-104. (2004).

[23] Cardwell, M : Patterns of relationships between teacher engagement and student achievement. Unpublished doctoral dissertation, St. John Fisher College. (2011).

[24] Hobfoll, S., Johnson, R., Ennis, N., \& Jackson, A.: Resource loss, resource gain, and emotional outcomes among inner-city women. Journal of Personality \& Social Psychology, 84, 632-643. (2003). http://dx.doi.org/10.1037//0022-3514.84.3.632

[25] Cotton, S. J., Dollard, M. F., \& Jonge, J. D.: Stress and student job design: Satisfaction, wellbeing, and performance in university students. International Journal of Stress Management, 9, 147-162. (2002). doi:10.1023/a:1015515714410

[26] Klassen, R. M., Yerdelen, S., \& Durksen, T. L.: Measuring teacher engagement: Development of the engaged teacher's scale (ETS). Journal of Educational Psychology, 2, 33-52. (2013).

[27] Beaton, D. E., Bombardier, C., Guillemin, F., \& Ferraz, M. B.: Guidelines for the Process of CrossCultural Adaptation of Self-Report Measures. Spine, 25, 3186-3191. (2000) doi:10.1097/00007632-200012150-00014.

[28] Marhamah, A.: Hubungan antara sikap guru terhadap anak berkebutuhan khusus dan dukungan instruksional guru di sekolah dasar inklusif. Unpublished master's thesis. Universitas Indonesia, Depok, Indonesia (2016).

[29] Schaufeli, W. B., \& Bakker, A. B. Job demands, job resources, and their relationship withburnout and engagement: A multi-sample study. Journal of Organizational Behavior,25,293315. (2004).

[30] Pedregon, C. A., Farley, R. L., Davis, A., Wood, J. M., \& Clark, R. D.: Social desirability, personality questionnaires, and the "better than average" effect. Personality and Individual Differences, 52, 213-217. (2012) doi:10.1016/j.paid.2011.10.022

[31] Skaalvik, E. M., \& Skaalvik, S. Teacher Self-Efficacy and Perceived Autonomy: Relations with Teacher Engagement, Job Satisfaction, and Emotional Exhaustion. Psychological Reports, 114, 68-77. (2014). 
[32] Shreve, S. D.: Teacher self-efficacy and the social skill development of included students with special needs in the general classroom setting. Unpublished master's thesis. University of North Carolina. (2006).

[32] Skaalvik, E. M., \& Skaalvik, S. (2007). Dimensions of Teacher Self-Efficacy and Relations with Strain Factors, Perceived Collective Teacher Efficacy, and Teacher Burnout. Journal of Educational Psychology, 99, 611-625.

[34] Upadyaya, K., Vartiainen, M., \& Salmela-Aro, K.: From job demands and resources to work engagement, burnout, life satisfaction, depressive symptoms, and occupational health. Burnout Research, 3, 101-108. (2016). http://dx.doi.org/10.1016/j.burn.2016.10.001. 